\title{
Review
}

\section{Preneoplastic lesions of the lung}

\author{
Alissa K Greenberg' ${ }^{1}$, Herman Yee 2,4 and William N Rom ${ }^{1,3,4}$
}

\begin{abstract}
1Department of Medicine, Division of Pulmonary and Critical Care Medicine, New York University School of Medicine, New York, USA. 2Department of Pathology, New York University School of Medicine, New York, USA.

${ }^{3}$ Department of Environmental Medicine, New York University School of Medicine, New York, USA.

${ }^{4}$ Kaplan Comprehensive Cancer Center, New York University School of Medicine, New York, USA.
\end{abstract}

Correspondence: Alissa K Greenberg - alissa.greenberg@med.nyu.edu

Received: 8 December 2001

Revisions requested: 28 January 2002

Revisions received: 19 February 2002

Accepted: 25 February 2002

Published: 4 April 2002
Respir Res 2002, 3:20

(C) 2002 BioMed Central Ltd

(Print ISSN 1465-9921; Online ISSN 1465-993X)

\begin{abstract}
Lung cancer is the leading cause of cancer deaths worldwide. If we can define and detect preneoplastic lesions, we might have a chance of improving survival. The World Health Organization has defined three preneoplastic lesions of the bronchial epithelium: squamous dysplasia/carcinoma in situ; atypical adenomatous hyperplasia; and diffuse idiopathic pulmonary neuroendocrine cell hyperplasia. These lesions are believed to progress to squamous cell carcinoma, adenocarcinoma and carcinoid tumors, respectively. In this review we summarize the data supporting the preneoplastic nature of these lesions, and delve into some of the genetic changes found in atypical adenomatous hyperplasia and squamous dysplasia/carcinoma in situ.
\end{abstract}

Keywords: bronchial epithelium, carcinogenesis, lung cancer, preneoplasia

\section{Introduction}

Lung cancer is the leading cause of cancer deaths worldwide [1] and the number of cases continues to increase. Smoking is the primary cause in the great majority of these cases. In Asia, particularly China, smoking rates continue to increase. Despite advances in therapy, the overall survival rate for lung cancer patients remains only $15 \%$. This poor survival is probably due to the relatively advanced stage of disease at diagnosis. To date, screening trials have had no significant impact on survival [2]. Screening can detect small (2-3 mm in size), asymptomatic nodules, but even these nodules may already be malignant, and therefore late in the course of the disease. Tumor cells have been found in the peripheral blood and bone marrow of patients with lung cancer of all sizes and stages $[3,4]$.

If lung cancer could be identified earlier - at a preneoplastic stage, before angiogenesis, invasion and micrometastases can occur - we might have a greater chance of improving survival. At this point, we have little information about possible progenitor lesions. Which lesions are preneoplastic? How and why do they progress? Is there any treatment that can prevent progression? Advances in molecular biology and microdissection techniques, and greater understanding of genetic changes involved in malignant transformation will aid in answering some of these questions. Advances in computerized tomography (CT), bronchoscopy and genomics technology raise the possibility that we may be able to detect these early lesions in vivo. Therefore, if preneoplastic lesions can be defined, and if appropriate therapies can be found, screening may then significantly improve survival.

To define preneoplastic lesions, we need to understand the molecular events that occur during bronchogenic carcinogenesis. Carcinogenesis is thought to be a multistep process consisting of the accumulation of gene mutations. Preneoplastic lesions may be morphological phenotypes of the different steps in this progression from normal to malig- 
nant tissue. We are just beginning to identify the presumed preneoplastic lesions in the bronchial epithelium.

The World Health Organization (WHO) recently published a tumor classification system that defines three different preneoplastic lesions of the bronchial epithelium: squamous dysplasia (SD) and carcinoma in situ (CIS), which may be precursors to squamous cell carcinoma; atypical adenomatous hyperplasia $(\mathrm{AAH})$, which may be the progenitor lesion for adenocarcinoma (particularly peripheral); and diffuse idiopathic pulmonary neuroendocrine cell hyperplasia (DIP-NECH), which may progress to carcinoid $[5,6]$. Additional possible preneoplastic lesions and conditions include: basal cell hyperplasia and squamous metaplasia (progressing to $\mathrm{SD}$ and $\mathrm{CIS}$ ); adenomatous hyperplasia (progressing to $\mathrm{AAH}$ ); angiogenic squamous dysplasia (consisting of microscopic projections into the bronchial lumen, surfaced by squamous dysplasia); and pulmonary fibrosis.

No preneoplastic lesion has been clearly identified for small cell carcinoma but, occasionally, SD/CIS can be seen in the adjacent airway mucosa. However, mucosa that appears normal but with significant genetic abnormalities is often found near small cell tumors, suggesting that these tumors might arise without going through a stage of morphologically recognizable preinvasive lesion [6].

In this review we will summarize the data supporting the classification of these various lesions as preneoplastic, and delve into some of the genetic changes found in $\mathrm{AAH}$ and SD/CIS (the most extensively studied of these lesions).

\section{Preneoplastic lesions}

The sequence of precursor lesions for squamous cell carcinoma may be hyperplasia-metaplasia-dysplasia-CIS. This progression of disease has long been recognized [7,8]. Basal cell hyperplasia is present when the basal cell layer is more than three cells thick, and SD is present when there is cytologic atypia. The WHO has classified SD and CIS as preneoplastic lesions. This classification also provides criteria for the distinction of mild, moderate, and severe dysplasia and CIS, based on the distribution of atypical cells and mitotic figures (Fig. 1). Several problems occur with this classification schema. The classification assumes that the lesions progress in an orderly manner, from hyperplasia to metaplasia, and then to increasing degrees of dysplasia, but this may not be the case. In addition, the grading of lesions is not uniform. Some investigators and clinicians use only two divisions - low grade versus high grade dysplasia. There is also some overlap between categories, and in any particular case a range of grades may be seen.

The sequence of precursor lesions for some pulmonary adenocarcinomas may be adenomatous hyperplasia to $\mathrm{AAH}$.
Recently, there has been great interest in $\mathrm{AAH}$ as the precursor for peripheral parenchymal adenocarcinoma, just as colon adenomas are the precursors for colon adenocarcinomas [9]. Lesions in AAH are usually small, asymptomatic, radiologically invisible, incidental microscopic findings in surgically resected lung. Larger lesions may be grossly visible on the cut surface of the lung, or as ground glass lesions on a chest CT. Cuboidal or low columnar cells, with the morphology of type 2 pneumocytes or Clara cells, line a group of alveoli, and are sometimes distributed around a terminal or respiratory bronchiole. Excess collagen and/or lymphocytes might cause alveolar wall thickening. Mitotic figures are unusual. Some lesions may have large amounts of scar tissue or a heavy lymphoid infiltrate (Fig. 1).

At an almost indistinguishable point, the more atypical $A A H$ becomes a bronchoalveolar cell carcinoma (BAC) (in current WHO classification, a noninvasive tumor growing by replacement of alveolar lining cells). The largest and most atypical $\mathrm{AAH}$ and BAC may actually be the same thing [6]. Larger AAH lesions may even have foci of invasion. Some authors have therefore suggested using size (for example 5 $\mathrm{mm}$ ) to distinguish between $\mathrm{AAH}$ and BAC. As in the squamous cell carcinoma sequence, other problems with the classification of $\mathrm{AAH}$ relate to reproducibility and uniformity, and lack of data about progression from hyperplasia to mild, and then severe, atypical hyperplasia

\section{Other possible preneoplastic conditions}

A precursor lesion for carcinoid tumors may be DIP-NECH, and some researchers have also suggested a possible relationship with other neuroendocrine tumors. In DIP-NECH, hyperplasia of airway neuroendocrine cells occurs without invasion beyond the basement membrane, in association with chronic inflammation or fibrosis in the lung. If the cells extend into the interstitium and are associated with fibrous tissue, the lesion is a carcinoid tumorlet (less than $5 \mathrm{~mm}$ ) or tumor (more than $5 \mathrm{~mm}$ ). This condition is rare, so very little data exists. Researchers have speculated that focal hyperplasia might provide a basis upon which neoplastic transformation is more likely to occur.

Several diffuse, fibrosing conditions are associated with an increased incidence of lung cancer, and may be considered preneoplastic conditions. Most recently, Hubbard and colleagues found an approximately sevenfold increase in the incidence of lung cancer in patients with idiopathic pulmonary fibrosis, compared to age and sex-matched control patients, even when controlled for smoking history [10]. In fibrosis associated with pneumoconioses, such as asbestosis or silicosis, it is unclear whether the tumor development is related to the fibrosis or to the carcinogenic nature of the exposure. The tumor development in diffuse pulmonary fibrosis may be associated with $\mathrm{AAH}$-like areas, con- 
Figure 1

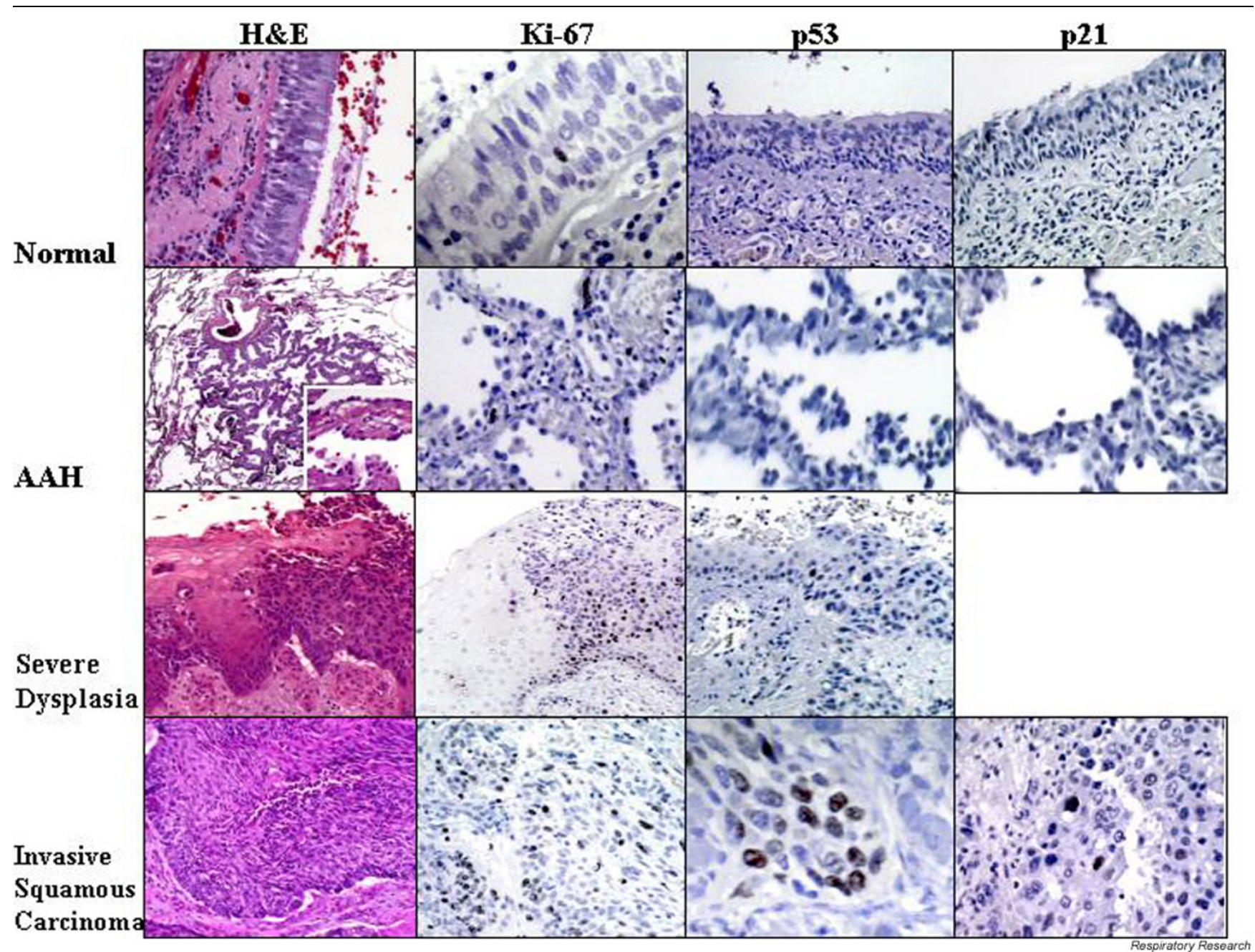

Normal bronchial mucosa, atypical adenomatous hyperplasia (AAH), squamous dysplasia and invasive squamous carcinoma have been stained for various markers. The first column shows hematoxylin and eosin (H\&E) tissue staining. The picture of AAH shows low (40X) and high (400x, inset) power images. The H\&E staining of squamous dysplasia shows relatively normal mucosa on the left of the image and severe dysplasia on the right. In severe dysplasia, there is considerable cellular pleiomorphism, coarse uneven chromatin, and little cell maturation. Vertical nuclei and mitotic figures are present in the lower two thirds of the mucosa. In invasive carcinoma the cytological aberration is extreme, mitoses occur at all levels of the mucosa, and maturation is absent. The second column shows staining for the proliferation marker, Ki-67, in the various lesions. Ki-67 is essentially negative in normal tissue. The images show increased $\mathrm{Ki}-67$ in $\mathrm{AAH}$, with a further increase in squamous dysplasia and carcinoma. In the third column, p53 is not observed in the normal bronchial mucosa or in $\mathrm{AAH}$, but is increased in both squamous dysplasia and squamous carcinoma. In the fourth column, p21 (p53-inducible cyclin dependent kinase inhibitor) is increased only in squamous carcinoma, but not in AAH or normal bronchial mucosa.

sisting of hyperplasia of alveolar lining cells, which may be atypical.

\section{Data supporting the preneoplastic nature of le- sions}

The data supporting the preneoplastic nature of these lesions is twofold, consisting of circumstantial evidence (lesions found in association with malignancies or in patients with high risk of developing lung cancer) and genetic evidence (genetic similarities found between tumors and their associated preneoplastic lesions).

\section{Circumstantial evidence}

Patients with primary cancer in the lung or upper aerodigestive tract have an increased risk of developing synchronous or metachronous second primaries [11]. This risk is likely to be related to chronic exposure of the bronchial tree to carcinogens. Cigarette smoke causes a field change in the mucosa with mutations demonstrable even in histologically normal areas ('field cancerization'). After smoking cessation, many of these mutations seem to persist indefinitely, so risk of lung cancer never reverts to that of a lifelong nonsmoker. Thus, broad areas of the tracheobronchial tree in 
high-risk patients are prone to premalignant or multifocal malignant change. The finding of these presumed premalignant lesions in cancer-bearing lungs or in patients at high risk of developing lung cancer is circumstantial evidence of the lesions' preneoplastic nature, and supports the field cancerization theory.

Several studies have shown an increased incidence of squamous metaplasia and dysplasia in the lungs of smokers. In 1979, Auerbach and colleagues described a range of histologic abnormalities in the lungs of smokers, from basal cell hyperplasia to CIS. They found dysplasia in up to $40 \%$ of heavy smokers [7,8]. In 1996, Agapitos and colleagues showed that in an autopsy study of 531 people who died of non-respiratory or non-cancer causes, the incidence of squamous metaplasia and dysplasia increased sequentially according to their degree of exposure to cigarette smoke (nonsmokers, those exposed to secondary smoke, exsmokers and smokers) [12]. Angiogenic squamous dysplasia has also been found in the airways of smokers before the occurrence of invasive carcinoma [13].

In contrast, we still have little information about the incidence of $\mathrm{AAH}$ or DIP/NECH in either smoking or nonsmoking populations. Autopsy studies of $\mathrm{AAH}$ are hampered by the presence of coincident pathology such as pneumonia, pneumonitis, or fibrosis, which make AAH almost impossible to find. Most studies seem to show a relatively low incidence of $\mathrm{AAH}$ in non-cancer-bearing lungs [14,15], and DIP/NECH is an extremely rare lesion.

The increased incidence of squamous metaplasia and dysplasia, $\mathrm{AAH}$, and DIP/NECH in lungs with the corresponding tumors, is strong circumstantial evidence that these lesions are preneoplastic. Squamous metaplasia, dysplasia, and CIS are frequently found in association with invasive cancer of all types [16]. It is more common to find $\mathrm{AAH}$ in lungs with adenocarcinoma or large cell carcinoma. The first descriptions of $\mathrm{AAH}$ in association with lung cancer were made in the 1980s $[9,17]$. Overall figures for $A A H$ incidence range from 4.4 to $9.6 \%$ in lungs removed for benign or metastatic disease, 3.3 to $11.1 \%$ in lungs resected for squamous cell carcinoma, and 23.2 to $34.5 \%$ in lungs resected for adenocarcinoma $[15,18,19]$. Zones of $\mathrm{AAH}$ are sometimes seen around the tumor. Niho and colleagues determined that, in seven patients with $\mathrm{AAH}$ and $\mathrm{BAC}$, the $\mathrm{AAH}$ lesions were all monoclonal, and in two cases the $\mathrm{BAC}$ and contiguous $\mathrm{AAH}$ had identical monoclonality [20]. These findings support the idea that the AAH-like edge that is sometimes observed around a peripheral adenocarcinoma is evidence of the pre-existing adenoma. Many patients in these and other studies had multiple $\mathrm{AAH}$ lesions and/or multiple synchronous primaries [18,21]. One patient was found to have 161 foci of $A A H$ [22]. The multifocal nature of $\mathrm{AAH}$ may explain the multicentricity that is observed with some adenocarcinomas.

Essentially our only evidence that DIP/NECH is a preneoplastic lesion is circumstantial, based on lungs found to have concurrent carcinoid tumors and DIP/NECH, and most of the data comes from case studies [23,24]. The finding of DIP/NECH may correlate with higher grade neuroendocrine malignancy. The relation between the hyperplasia and the tumor, if any, is not currently understood.

\section{Genetic evidence}

Alterations in gene expression and chromosome structure known to be associated with malignant transformation can be demonstrated in squamous metaplasia, dysplasia and $\mathrm{CIS}$, as well as in AAH. In this respect, DIP/NECH has not been studied. The changes might be sequential, and their frequency and number seem to increase with atypia in both the metaplasia-dysplasia-CIS sequence and the $\mathrm{AAH}$-adenocarcinoma sequence. These changes can be seen both as proof of the preneoplastic nature of the lesions, and as possible markers of transformation (or imminent transformation). They may also become tools for early detection.

\section{Cell proliferation markers and cell cycle regulators}

Hyperproliferation and loss of cell cycle control seem to be early events in malignant transformation. Several studies have looked at different proliferation markers and cell cycle regulators in preneoplastic lesions. Staining for proliferation markers (PCNA and Ki-67) increased with increasing atypia in both squamous cell dysplasias and AAH $[15,25]$. Several studies have found the growth fraction in $A A H$ is intermediate between normal lung tissue and adenocarcinoma $[26,27]$.

Of the cell cycle regulators, P16 expression is lost in moderate dysplasia, CIS, and squamous cell carcinoma, but its loss is rare in AAH and adenocarcinoma. Cyclin D1 and E are overexpressed in hyperplasia, metaplasia, dysplasia, and $\mathrm{CIS}$, as well as $\mathrm{AAH}$, and increasing levels are seen with increasing grade. Levels were, however, lower in BAC. Loss of $\mathrm{Rb}$ (Retinoblastoma gene), which plays and important role in cell cycle regulation during G0/G1, was not seen in preinvasive lesions of either type $[26,28,29]$.

\section{DNA ploidy}

Studies of the DNA content of cell nuclei, as a measure of chromosomal gain or loss, are used to assess the degree of nuclear aberration in a malignant cell population. Studies in both squamous cell metaplasia/dysplasia and $\mathrm{AAH}$ have shown progressive, increased aneuploidy with increasing atypia [17,30,31]. Hirano and colleagues showed that, in squamous metaplasia, $8 \%$ of low grade lesions and $33 \%$ of high grade lesions were aneuploid [25]. In a study of $A A H$, Nakanishi and colleagues demonstrated DNA aneuploidy 
in none of the low grade $\mathrm{AAH}, 25 \%$ of high grade, and $34.6 \%$ of BAC [32]. A few studies have shown aneuploidy of chromosome 7 in both the bronchial epithelium of patients with high risk for lung cancer (smokers, uranium miners) and in preneoplastic lesions, with an increase in the percentage of aneuploid cells from preinvasive to invasive lesions $[33,34]$.

\section{$p 53$ and the $p 53$ transcription pathway}

Abnormalities of p53 expression are frequent in lung carcinoma, and many studies have found increased or abnormal p53 in both the squamous metaplasia to dysplasia sequence, and AAH. Several studies in the squamous cell carcinoma sequence have found an increase in stainable p53, with increasingly severe dysplasia, ranging in various studies from an average of $5 \%$ in low grade dysplasia to $60.4 \%$ in high grade dysplasia $[25,28,29,35-38]$. Studies of p53 expression in AAH have yielded similar results, showing increasing p53 expression with increasing atypia. The overall levels, however, are somewhat lower in these preneoplastic lesions indicating, perhaps, that $p 53$ mutation is a later event in peripheral adenocarcinogenesis than in squamous carcinogenesis $[15,39,40]$. In contrast, the studies have found no staining in normal epithelium, and minimal staining in either metaplasia or adenomatous hyperplasia without atypia.

Other studies have looked at gene mutation instead of expression. These studies have shown that $p 53$ gene mutation in both $\mathrm{AAH}$ and bronchiolar epithelial dysplasia is sometimes identical to, and sometimes different from, a concurrent tumor [41-44]. In some studies the mutations were seen with increasing frequency depending on the degree of atypia [38,41]. Brambilla and colleagues found p53 expression in all cases of SD/CIS from cancer-bearing lungs, but similar lesions from lungs with no cancer showed no staining, suggesting that stabilization of p53 in the preinvasive lesion had a high predictive value for invasion [45].

Some authors have attempted to look at the interaction between the expression of p53 and that of other members of the p53 signaling pathway. Hayashi and colleagues found that in reactive lesions there is a correlation between p53 and p21 (p53-inducible cyclin dependent kinase inhibitor) expression, and that this correlation is lost in both $\mathrm{AAH}$ and carcinomas [46]. Their data suggest that p21 expression may become $\mathrm{p} 53$ independent during transformation, even at an early AAH stage. The protein MDM-2 binds to p53 and eliminates its ability to function as a transcription factor. Alterations in MDM-2 expression have been found in preneoplastic lesions [47]. Other authors have found an apparent deregulation of the p53 apoptosis transcription pathway in precursor bronchial lesions of lung cancer. The protein, Bcl-2, inhibits programmed cell death, and overexpression provides a survival advantage. This protein is over- expressed in lung cancer $(25 \%$ of squamous cell carcinoma, $10 \%$ of adenocarcinoma, $64 \%$ of small cell carcinoma) $[48,49]$. Overexpression has also been seen in preinvasive bronchial lesions, with some association with increasing degree of dysplasia $[28,37,50]$. In one of these studies, Bcl-2 overexpression was associated with Bax (an inducer of apoptosis) downregulation in preinvasive lesions and these changes were maintained during invasion [45]. Expressions of Bax, Bcl-2 and p21 did not correlate with p53 status. The authors of this study concluded that Bax/ $\mathrm{Bcl}-2$ imbalance contributes to clonal expansion during premalignant states.

\section{Telomerase}

Telomerase is thought to play a role in conferring immortality on tumor cell populations. It may prevent progressive telomere shortening and therefore cellular senescence. In adult somatic cells telomerase is inactive, whereas the enzyme is activated and expressed in most human cancers. Yashima and colleagues looked at telomerase expression and activity in more than 200 preneoplastic and neoplastic lesions from 40 patients: 34 with lung cancer; 5 with CIS; and 1 without lung cancer [51]. They found telomerase activity in $95-100 \%$ of CIS and invasive disease, in 70 to $80 \%$ of both hyperplastic and dysplastic bronchial epithelium, and in only $20 \%$ of normal epithelium. When they assayed activity, they found preinvasive lesions had enzyme activity only 3-4 times normal, whereas in invasive disease, activity was more than 40 times normal. Telomerase deregulation increased with increasing epithelial changes. In contrast, alveolar cells and $\mathrm{AAH}$ were negative for telomerase.

k-ras

The ras genes play an important role in signal transduction and cellular proliferation (through the mitogen-activated protein kinase pathways) and were among the first oncogenes identified. Mutation of $\mathrm{k}$-ras is found in about $30 \%$ of non-small cell carcinoma, and is more common in adenocarcinoma than in squamous cell carcinoma. Accordingly, studies have found k-ras mutation more commonly in AAH than in SD. The AAH lesions often have different base changes at codon 12 compared to the concurrent adenocarcinoma. This finding is consistent with the notion that $\mathrm{AAH}$ represents field cancerization in the lung periphery [52-54]. Several studies have found that parenchymal tumors and $\mathrm{AAH}$ have k-ras mutation more frequently than adenocarcinoma in the airways. This finding supports the classification of adenocarcinomas into bronchial and parenchymal subtypes, and suggests the importance of $A A H$ in development of parenchymal cancers. The bronchial subtype might arise from bronchial epithelial dysplasia [55].

\section{FHIT}

The FHIT gene (fragile histidine triad tumor suppressor gene) is frequently deleted in many carcinomas, including 
lung. The gene covers a genomic region at 3p14.2, which spans the most active of the common human chromosomal fragile regions FRA3B. These fragile sites might be especially susceptible to carcinogen damage. The FHIT gene encodes a protein that hydrolyzes diadenosine triphosphate to ADP and AMP in vitro. Although the in vivo function of this protein is not known, it may play a role in cell death through apoptosis and/or may affect cell proliferation. Loss of FHIT protein is the most frequent alteration in non-small cell lung carcinoma and precancerous lesions (both squamous cell and adenocarcinoma). The frequency of loss increases as the grade of dysplasia increases [56]. In some studies, loss of FHIT protein expression was almost universal by the severe SD/CIS stage. This loss is significantly more frequent in tumors and preneoplastic lesions of smokers (75\%) than of nonsmokers (39\%), and is an independent and more frequent event than p53 overexpression. It is more common in squamous cell carcinoma $(87 \%)$ than in adenocarcinoma (57\%) [57-60]. Loss of FHIT protein expression is also common in small cell carcinomas and neuroendocrine lung tumors. In one study, loss of heterozygosity $(\mathrm{LOH})$ at this locus was found in atypical carcinoids as well [61].

\section{Genomic alterations and $\mathrm{LOH}$ studies}

Several chromosomal sites are most frequently involved in lung cancer. The most common and earliest changes in both squamous cell carcinoma and adenocarcinoma seem to involve allele-specific loss of genome at $3 p$ and $9 p$ and perhaps $17 q$, among others $[22,43]$. These changes involve all regions of the respiratory tract, and occur with increasing frequency with increasing atypia $[41,43,44,62-$ $66]$. Some of these changes have also been seen in the normal appearing bronchial epithelium of chronic smokers [67-69]. Studies suggest that these deletions occur more frequently in squamous metaplasia/dysplasia than in $\mathrm{AAH}$, suggesting they may be a later event in adenocarcinoma pathogenesis [41].

In some of the most extensive studies to date, Wistuba and colleagues looked at $\mathrm{LOH}$ at 10 chromosomal regions frequently deleted in lung cancer $[68,70]$. In one study they examined normal tissue, SD, CIS, and invasive tumors from 12 patients with lung cancer. In a subsequent study they looked at 97 lung cancers and 54 preneoplastic lesions from patients without lung cancer. At one or more regions $\mathrm{LOH}$ was common in normal-appearing mucosa, but they found a progressive increase in overall LOH frequency and size, along with increasingly severe histopathological changes, in both lungs with lung cancer and those without. In CIS and invasive squamous cell carcinoma, $3 p$ allele loss was almost universal. The earliest and most frequent regions of loss were at 3p21, 22-24, 25 and 9p21. Losses at 3p14.2, 14-21 began to appear in the hyperplastic/ metaplastic lesions. Loss of $\mathrm{p} 53$ and $\mathrm{Rb}$ loci was present in more advanced lesions. The same allele was lost in $90 \%$ of corresponding preneoplastic and invasive lesions. The authors hypothesized that many sequentially occurring, allele-specific changes begin in independent foci of the bronchial epithelium, early in the pathogenesis of squamous cell carcinoma.

Overall, the data seem to show that localized, specific $\mathrm{LOH}$ of $3 p$ and $9 p$ occurs very early in the evolution of preinvasive disease of the bronchial epithelium. This is seen even in phenotypically normal or hyperplasic epithelium. As the lesions advance, more $3 p$ deletions including 14.2 begin to appear, as does $17 \mathrm{p} \mathrm{LOH}$, and perhaps other regional deletions. By the time the stage of severe SD/CIS is reached, there is extensive loss of $3 p$ and persistent loss of the $9 p$ and $17 p$ regions.

\section{Methylation}

Recently, there has been increased interest in the significance of the methylation of genes and their promoters. Aberrant methylation of gene promoters can silence gene expression. In an animal model exposed to tobacco carcinogen, methylation was frequent in preneoplastic lesions [71]. In human lung cancer, $p 16, p 53$ and $\mathrm{k}$-ras promoter hypermethylation has been seen. Aberrant methylation of the promoter regions of other tumor suppressors may also play a role in carcinogenesis. A few studies have begun to look at methylation patterns in preneoplastic lesions. Until now, $p 16$ tumor suppressor gene promoter methylation has been the most studied [72]. Belinsky and colleagues found that the frequency of methylation increased during progression from basal cell hyperplasia to squamous metaplasia to SD/CIS [71]. Zochbauer-Muller et al. looked at promoter methylation of multiple genes, and found that methylation was common in the promoter region of multiple genes in both tumors and associated, nonmalignant tissues [73].

\section{Other possible markers of transformation}

Vascular growth is an important aspect of malignant transformation. Increasing neovascularization and vascular count has been found with increasing dysplasia of lesions of the bronchial tree [74]. Accordingly, expression of vascular endothelial growth factor was found to increase from normal tissue to SD to CIS to invasive cancer [75]. Changes in the extracellular matrix may also distinguish normal, preinvasive, and malignant lesions. One study found increased matrix disarrangement of the basement membrane zone with increasing degree of neoplasia [76].

Many other proteins have been found to have either increased or decreased expression, correlating with increasing histopathologic abnormality. In the metaplasiadysplasia-squamous cell carcinoma sequence, some of the proteins that may have increased expression include hyaluronan [76], epidermal growth factor receptor [36], cal- 
cyclin [77], fatty acid synthase [78], thrombomodulin [79], and epithelial cellular adhesion molecule (17-1A) [80]. In the $\mathrm{AAH}$-adenocarcinoma sequence, some of the proteins with increased expression include carcinoembryonic antigen [81], surfactant apoprotein A [81] (although one study [82] found that surfactant apoprotein A seemed to decrease as the lesions advanced), cytochrome p450 [81], cerbB2 (product of the neu oncogene) [39], and cyclooxygenase $2[83,84]$.

Many other potential markers have not yet been investigated in preneoplastic lesions, but they are abnormally expressed in lung cancer. Expression of Hif $1 \alpha$ is increased in most types of malignancy, including lung [85]. A tumor suppressor gene, $\mathrm{Rb}$-related gene $\mathrm{pRb} 2 / \mathrm{p} 130$, may play a role in lung cancer development [86]. Expression of the 14-3-3 family of proteins is increased in lung cancer tissues [87]. Another potential marker is HnRNPB1, a protein that is found in $100 \%$ of squamous cell carcinoma of the lung, and expression in the sputum has been correlated with risk of lung cancer development in certain populations $[88,89]$. The presence of DNA adducts may also potentially identify preneoplastic lesions [90].

\section{Clinical studies of lesions and risks of progression}

The cause and effect relationship between these various genetic abnormalities and morphologic changes is unknown. Given the relationship between many of these finding and the grades of atypia, abnormal gene expression might be responsible for the changes in morphology. The phenotype/histology, however, is reversible in some cases. Very few clinical studies have looked at the outcome of preneoplastic lesions. Based on studies of epithelial dysplasia in sputum samples, it might take up to 10 years for invasion to occur [91]. Some studies have shown that when atypia is seen in the sputum, it may take 6-36 months for a lesion to be visible bronchoscopically [6]. In a study of patients who underwent fluorescence bronchoscopy at regular intervals for at least six months, progression to invasive cancer occurred in $5 / 9$ patients with CIS. Neoplastic lesions were detected at other sites in 4/9 patients [92]. Ponticello and colleagues followed a group of smokers without lung cancer for four years. Initially, 22 bronchial dysplastic lesions were detected. Ten lung cancers developed during follow up, seven of which developed in lesions that had expressed $\mathrm{p} 53$. The authors suggested that p53 immunohistochemistry can identify the bronchial preneoplastic lesions that will progress to lung cancer [93].

It is almost impossible to follow AAH in a longitudinal study, since the lesions are generally only identified incidentally in lung resected for other reasons. It has been found that, in patients who have had resections for adenocarcinoma, the concurrent presence of AAH does not appear to affect survival $[19,94]$. In one study the concurrent presence of AAH actually seemed to be a favorable prognostic indicator [95]. The fate of DIP/NECH is also unknown.

\section{Conclusion}

Although great strides have been made in the last decade in describing the sequence of lung carcinogenesis, we need much more information to effectively intervene in this process. Studies in the last few years have clearly shown that there is an accumulation of various genetic abnormalities, which correlate with increasing morphologic changes, in both the squamous cell carcinoma and adenocarcinoma sequence. Very little is known so far about the details of carcinoid/neuroendocrine or small cell carcinoma development. Changes in the $p 53$ gene and 3p LOH have been the most extensively studied mutations, however there are many other potential markers. We do not know which genetic changes are most important, or at what stage the process is irreversible. It is likely that several different combinations of abnormalities can cause transformation. Improvements in CT technology may allow us to detect AAH in vivo, and advances in bronchoscopy, including fluorescence bronchoscopy, may aid in the detection of preneoplastic central bronchial lesions (although to date, the specificity is relatively low). Even if we are able to detect the histologic preneoplastic lesions, however, we still do not know the risk of progression. The histologic lesions may be reversible if carcinogen exposure ceases, although the genomic alterations do not regress. Therefore, if we are to affect lung cancer mortality, it is important to identify the genetic lesions that predispose to malignant transformation so that these can be detected along with the more variable histologic changes. Just as importantly, there is a need to develop a means to prevent this transformation. In this review we have summarized the available information on genetic and biochemical changes in presumed preneoplastic lesions of the bronchial epithelium. This review thus provides a basis for further investigations in this area.

\section{Abbreviations}

$\mathrm{AAH}=$ atypical adenomatous hyperplasia; $\mathrm{BAC}=$ bronchoalveolar cell carcinoma; $\mathrm{CIS}=$ carcinoma in situ; $\mathrm{CT}=$ computerized tomography; DIP-NECH = diffuse idiopathic pulmonary neuroendocrine cell hyperplasia; $\mathrm{LOH}=$ loss of heterozygosity; $\mathrm{SD}=$ squamous dysplasia; $\mathrm{WHO}$ $=$ World Health Organization.

\section{References}

1. Rom WN, Hay JG, Lee TC, Jiang Y, Tchou-Wong KM: Molecular and genetic aspects of lung cancer. Am J Respir Crit Care Med 2000, 161:1355-1367

2. Patz EF Jr, Goodman PC, Bepler G: Screening for lung cancer. $N$ Engl J Med 2000, 343:1627-1633

3. Peck K, Sher YP, Shih JY, Roffler SR, Wu CW, Yang PC: Detection and quantitation of circulating cancer cells in the peripheral blood of lung cancer patients. Cancer Res 1998, 58:27612765

4. Pantel K, Izbicki J, Passlick B, Angstwurm M, Haussinger K, Thetter $\mathrm{O}$, Riethmuller $\mathrm{G}$ : Frequency and prognostic significance of isolated tumour cells in bone marrow of patients with non-smallcell lung cancer without overt metastases. Lancet 1996, 347:649-653 
5. Travis CT WD, Corrin B, in collaboration with pathologists from 14 countries: Histological typing of lung and pleural tumours. In World Health Organization International Histological Classification of Tumours. 1999

6. Kerr KM: Pulmonary preinvasive neoplasia. J Clin Pathol 2001, 54:257-271

7. Auerbach O, Hammond EC, Garfinkel L: Changes in bronchial epithelium in relation to cigarette smoking, 1955-1960 vs 1970-1977. N Engl J Med 1979, 300:381-385

8. Auerbach O, Stout AP, Hammond EC, Garfinkel L: Changes in bronchial epithelium in relation to sex, age, residence, smoking and pneumonia. Nord Hyg Tidskr 1962, 267:111-119

9. Miller RR, Nelems B, Evans KG, Muller NL, Ostrow DN: Glandular neoplasia of the lung. A proposed analogy to colonic tumors. Cancer 1988, 61:1009-1014

10. Fraire $A E$, Greenberg SD: Carcinoma and diffuse interstitial fibrosis of lung. Cancer 1973, 31:1078-1086

11. Franklin WA: Diagnosis of lung cancer: pathology of invasive and preinvasive neoplasia. Chest 2000, 117:80S-89S

12. Agapitos E, Mollo F, Tomatis L, Katsouyanni K, Lipworth L, Delsedime L, Kalandidi A, Karakatsani A, Riboli E, Saracci R, Trichopoulos $D$ : Epithelial, possibly precancerous, lesions of the lung in relation to smoking, passive smoking, and socio-demographic variables. Scand J Soc Med 1996, 24:259-263

13. Keith RL, Miller YE, Gemmill RM, Drabkin HA, Dempsey EC, Kennedy TC, Prindiville S, Franklin WA: Angiogenic squamous dysplasia in bronchi of individuals at high risk for lung cancer. Clin Cancer Res 2000, 6:1616-1625

14. Sterner DJ, Mori M, Roggli VL, Fraire AE: Prevalence of pulmonary atypical alveolar cell hyperplasia in an autopsy population: a study of 100 cases. Mod Pathol 1997, 10:469-473

15. Yokose T, Ito $Y$, Ochiai A: High prevalence of atypical adenomatous hyperplasia of the lung in autopsy specimens from elderly patients with malignant neoplasms. Lung Cancer 2000, 29:125-130

16. Auerbach O, Saccomanno G, Kuschner M, Brown RD, Garfinkel L: Histologic findings in the tracheobronchial tree of uranium miners and non-miners with lung cancer. Cancer 1978, 42:483-489

17. Kodama T, Biyajima S, Watanabe S, Shimosato Y: Morphometric study of adenocarcinomas and hyperplastic epithelial lesions in the peripheral lung. Am J Clin Pathol 1986, 85:146-151

18. Weng SY, Tsuchiya E, Kasuga T, Sugano H: Incidence of atypical bronchioloalveolar cell hyperplasia of the lung: relation to histological subtypes of lung cancer. Virchows Arch A Pathol Anat Histopathol 1992, 420:463-471

19. Chapman AD, Kerr KM: The association between atypical adenomatous hyperplasia and primary lung cancer. $\mathrm{Br} J$ Cancer 2000, 83:632-636

20. Niho S, Yokose T, Suzuki K, Kodama T, Nishiwaki Y, Mukai K: Monoclonality of atypical adenomatous hyperplasia of the lung. $A m$ $J$ Pathol 1999, 154:249-254

21. Dohmoto K, Fujita J, Ohtsuki Y, Kotsuna N, Mitsunaka H, Kuwabara $\mathrm{H}$, Takahara J: Synchronous four primary lung adenocarcinoma associated with multiple atypical adenomatous hyperplasia. Lung Cancer 2000, 27:125-130

22. Anami Y, Matsuno Y, Yamada T, Takeuchi T, Nakayama H, Hirohashi S, Noguchi M: A case of double primary adenocarcinoma of the lung with multiple atypical adenomatous hyperplasia. Pathol Int 1998, 48:634-640

23. Miller RR, Muller NL: Neuroendocrine cell hyperplasia and obliterative bronchiolitis in patients with peripheral carcinoid tumors. Am J Surg Pathol 1995, 19:653-658

24. Aguayo SM, Miller YE, Waldron JA Jr, Bogin RM, Sunday ME, Staton GW Jr, Beam WR, King TE Jr: Brief report: idiopathic diffuse hyperplasia of pulmonary neuroendocrine cells and airways disease. N Engl J Med 1992, 327:1285-1288

25. Hirano T, Franzen B, Kato H, Ebihara Y, Auer G: Genesis of squamous cell lung carcinoma. Sequential changes of proliferation, DNA ploidy, and p53 expression. Am J Pathol 1994, 144:296302

26. Kurasono $Y$, Ito $T$, Kameda $Y$, Nakamura N, Kitamura H: Expression of cyclin D1, retinoblastoma gene protein, and p16 MTS1 protein in atypical adenomatous hyperplasia and adenocarcinoma of the lung. An immunohistochemical analysis. Virchows Arch 1998, 432:207-215
27. Carey FA, Wallace WAH, Fergusson RJ, Kerr KM, Lamb D: Alveolar atypical hyperplasia in association with primary pulmonary adenocarcinoma: a clinicopathological study of 10 cases. Thorax 1992, 47:1041-1043

28. Brambilla E, Gazzeri S, Moro D, Lantuejoul S, Veyrenc S, Brambilla $\mathrm{C}$ : Alterations of Rb pathway (Rb-p16INK4-cyclin D1) in preinvasive bronchial lesions. Clin Cancer Res 1999, 5:243-250

29. Lonardo F, Rusch V, Langenfeld J, Dmitrovsky E, Klimstra DS: Overexpression of cyclins D1 and E is frequent in bronchial preneoplasia and precedes squamous cell carcinoma development. Cancer Res 1999, 59:2470-2476

30. Smith AL, Hung J, Walker L, Rogers TE, Vuitch F, Lee E, Gazdar AF: Extensive areas of aneuploidy are present in the respiratory epithelium of lung cancer patients. $\mathrm{Br} J$ Cancer 1996, 73:203-209

31. Mori M, Chiba R, Takahashi T: Atypical adenomatous hyperplasia of the lung and its differentiation from adenocarcinoma. Characterization of atypical cells by morphometry and multivariate cluster analysis. Cancer 1993, 72:2331-2340

32. Nakanishi K, Hiroi S, Kawai T, Suzuki M, Torikata C: Argyrophilic nucleolar-organizer region counts and DNA status in bronchioloalveolar epithelial hyperplasia and adenocarcinoma of the lung. Hum Pathol 1998, 29:235-239

33. Zojer N, Dekan G, Ackermann J, Fiegl M, Kaufmann H, Drach J, Huber $\mathrm{H}$ : Aneuploidy of chromosome 7 can be detected in invasive lung cancer and associated premalignant lesions of the lung by fluorescence in situ hybridisation. Lung Cancer 2000, 28:225-235

34. Lechner JF, Neft RE, Gilliland FD, Crowell RE, Belinsky SA: Molecular identification of individuals at high risk for lung cancer. $R a-$ diat Oncol Invest 1997, 5:103-105

35. Bennett WP, Colby TV, Travis WD, Borkowski A, Jones RT, Lane DP, Metcalf RA, Samet JM, Takeshima Y, Gu JR: p53 protein accumulates frequently in earlybronchial neoplasia. Cancer Res 1993, 53:4817-4822

36. Rusch V, Klimstra D, Linkov I, Dmitrovsky E: Aberrant expression of p53 or the epidermal growth factor receptor is frequent in early bronchial neoplasia and coexpression precedes squamous cell carcinoma development. Cancer Res 1995, 55:13651372

37. Katabami M, Dosaka-Akita H, Honma K, Kimura K, Fujino M, Uchida Y, Mikami H, Ohsaki Y, Kawakami Y, Kikuchi K: p53 and Bcl-2 expression in pneumoconiosis-related pre-cancerous lesions and lung cancers: frequent and preferential p53 expression in pneumoconiotic bronchiolar dysplasias. Int J Cancer 1998 75:504-511

38. Chyczewski L, Chyczewska E, Niklinski J, Niklinska W, Sulkowska M, Naumnik W, Kovalchuk O: Morphological and molecular aspects of cancerogenesis in the lung. Folia Histochem Cytobiol 2001, 39:149-152

39. Kerr KM, Carey FA, King G, Lamb D: Atypical alveolar hyperplasia: relationship with pulmonary adenocarcinoma, $\mathrm{p53}$, and cerbB-2 expression. J Pathol 1994, 174:249-256

40. Slebos RJ, Baas IO, Clement MJ, Offerhaus GJ, Askin FB, Hruban $\mathrm{RH}$, Westra WH: p53 alterations in atypical alveolar hyperplasia of the human lung. Hum Pathol 1998, 29:801-808

41. Kohno H, Hiroshima K, Toyozaki T, Fujisawa T, Ohwada H: p53 mutation and allelic loss of chromosome $3 p$, 9p of preneoplastic lesions in patients with nonsmall cell lung carcinoma. Cancer 1999, 85:341-347

42. Sundaresan V, Ganly P, Hasleton P, Rudd R, Sinha G, Bleehen NM, Rabbitts P: p53 and chromosome 3 abnormalities, characteristic of malignant lung tumours, are detectable in preinvasive lesions of the bronchus. Oncogene 1992, 7:1989-1997

43. Sozzi G, Miozzo M, Donghi R, Pilotti S, Cariani CT, Pastorino U, Della Porta G, Pierotti MA: Deletions of $17 p$ and p53 mutations in preneoplastic lesions of the lung. Cancer Res 1992, 52:6079-6082

44. Nishisaka T, Takeshima $Y$, Inai K: Evaluation of p53 gene mutation and loss of heterozygosity of $3 p, 9 p$ and $17 p$ in precancerous lesions of 29 lung cancer patients. Hiroshima J Med Sci 2000, 49:109-116

45. Brambilla E, Gazzeri S, Lantuejoul S, Coll JL, Moro D, Negoescu A, Brambilla C: p53 mutant immunophenotype and deregulation of p53 transcription pathway (Bcl2, Bax, and Waf1) in precursor bronchial lesions of lung cancer. Clin Cancer Res 1998, 4:1609-1618 
46. Hayashi $\mathrm{H}$, Miyamoto $\mathrm{H}$, Ito $T$, Kameda $\mathrm{Y}$, Nakamura $\mathrm{N}$, Kubota $\mathrm{Y}$, Kitamura $\mathrm{H}$ : Analysis of p21Waf1/Cip1 expression in normal, premalignant, and malignant cells during the development of human lung adenocarcinoma. Am J Pathol 1997, 151:461-470

47. Rasidakis A, Orphanidou D, Kalomenidis J, Papamichalis G, Toumbis M, Lambaditis J, Sacharidou A, Papastamatiou H, Jordanoglou J: Expression of $\mathrm{mdm}-2$ protein in neoplastic, preneoplastic, and normal bronchial mucosa specimens: comparative study with p53 expression. Hybridoma 1998, 17:339345

48. Pezzella F, Turley H, Kuzu I, Tungekar MF, Dunnill MS, Pierce CB, Harris A, Gatter KC, Mason DY: bcl-2 protein in non-small-cell lung carcinoma. $N$ Engl J Med 1993, 329:690-694

49. Kennedy MM, Lamb D, King G, Kerr KM: Cell proliferation, cell loss and expression of bcl-2 and p53 in human pulmonary neoplasms. Br J Cancer 1997, 75:545-547

50. Walker C, Robertson L, Myskow M, Dixon G: Expression of the BCL-2 protein in normal and dysplastic bronchial epithelium and in lung carcinomas. $\mathrm{Br} J$ Cancer 1995, 72:164-169

51. Yashima K, Litzky LA, Kaiser L, Rogers T, Lam S, Wistuba II, Milchgrub S, Srivastava S, Piatyszek MA, Shay JW, Gazdar AF: Telomerase expression in respiratory epithelium during the multistage pathogenesis of lung carcinomas. Cancer Res 1997, 57:2373-2377

52. Sugio K, Kishimoto Y, Virmani AK, Hung JY, Gazdar AF: K-ras mutations are a relatively late event in the pathogenesis of lung carcinomas. Cancer Res 1994, 54:5811-5815

53. Sagawa M, Saito Y, Fujimura S, Linnoila RI: K-ras point mutation occurs in the early stage of carcinogenesis in lung cancer. $\mathrm{Br}$ $J$ Cancer 1998, 77:720-723

54. Westra WH, Baas IO, Hruban RH, Askin FB, Wilson K, Offerhaus GJ, Slebos RJ: K-ras oncogene activation in atypical alveolar hyperplasias of the human lung. Cancer Res 1996, 56:2224 2228

55. Cooper CA, Carby FA, Bubb VJ, Lamb D, Kerr KM, Wyllie AH: The pattern of $\mathrm{K}$-ras mutation in pulmonary adenocarcinoma defines a new pathway of tumour development in the human lung. J Pathol 1997, 181:401-404

56. Sozzi G, Pastorino U, Moiraghi L, Tagliabue E, Pezzella F, Ghirelli C, Tornielli S, Sard L, Huebner K, Pierotti MA, Croce CM, Pilotti S Loss of FHIT function in lung cancer and preinvasive bronchia lesions. Cancer Res 1998, 58:5032-5037

57. Huebner K, Druck T, Siprashvili Z, Croce CM, Kovatich A, McCue PA: The role of deletions at the FRA3B/FHIT locus in carcinogenesis. Recent Results Cancer Res 1998, 154:200-215

58. Fong KM, Biesterveld EJ, Virmani A, Wistuba I, Sekido Y, Bader SA, Ahmadian M, Ong ST, Rassool FV, Zimmerman PV, Giaccone G, Gazdar AF, Minna JD: FHIT and FRA3B 3p14.2 allele loss are common in lung cancer and preneoplastic bronchial lesions and are associated with cancer-related FHIT cDNA splicing aberrations. Cancer Res 1997, 57:2256-2267

59. Tseng JE, Kemp BL, Khuri FR, Kurie JM, Lee JS, Zhou X, Liu D, Hong WK, Mao L: Loss of Fhit is frequent in stage I non-small cell lung cancer and in the lungs of chronic smokers. Cancer Res 1999, 59:4798-4803

60. Sozzi G, Sard L, De Gregorio L, Marchetti A, Musso K, Buttitta F Tornielli S, Pellegrini S, Veronese ML, Manenti G, Incarbone M, Chella A, Angeletti CA, Pastorino U, Huebner K, Bevilaqua G, Pilotti S, Croce CM, Pierotti MA: Association between cigarette smoking and FHIT gene alterations in lung cancer. Cancer Res 1997, 57:2121-2123

61. Kovatich A, Friedland DM, Druck T, Hadaczek P, Huebner K Comis RL, Hauck W, McCue PA: Molecular alterations to human chromosome $3 p$ loci in neuroendocrine lung tumors. Cancer 1998, 83:1109-1117

62. Hung J, Kishimoto Y, Sugio K, Virmani A, Mclntire DD, Minna JD, Gazdar AF: Allele-specific chromosome 3p deletions occur at an early stage in the pathogenesis of lung carcinoma. JAMA 1995, 273:1908

63. Endo C, Sagawa M, Sato M, Chen Y, Sakurada A, Aikawa H, Taka hashi S, Usuda K, Saito Y, Fujimura S: Sequential loss of heterozygosity in the progression of squamous cell carcinoma of the lung. Br J Cancer 1998, 78:612-615

64. Yamasaki M, Takeshima Y, Fujii S, Kitaguchi S, Matsuura M, Tagawa K, Inai K: Correlation between genetic alterations and histopathological subtypes in bronchiolo-alveolar carcinoma and atypical adenomatous hyperplasia of the lung. Pathol Int 2000, 50:778-785

65. Kishimoto Y, Sugio K, Hung JY, Virmani AK, Mclntire DD, Minna JD Gazdar AF: Allele-specific loss in chromosome 9p loci in preneoplastic lesions accompanying non-small cell lung cancers. J Nat/ Cancer Inst 1995, 87:1224-1229

66. Chung GT, Sundaresan V, Hasleton P, Rudd R, Taylor R, Rabbitts $\mathrm{PH}$ : Sequential molecular genetic changes in lung cancer development. Oncogene 1995, 11:2591-2598

67. Wistuba II, Lam S, Behrens C, Virmani AK, Fong KM, LeRiche J Samet JM, Srivastava S, Minna JD, Gazdar AF: Molecular damage in the bronchial epithelium of current and former smokers. $J$ Natl Cancer Inst 1997, 89:1366-1373

68. Wistuba II, Behrens C, Virmani AK, Mele G, Milchgrub S, Girard L Fondon JW 3rd, Garner HR, McKay B, Latif F, Lerman MI, Lam S Gazdar AF, Minna JD: High resolution chromosome 3p allelotyping of human lung cancer and preneoplastic/preinvasive bronchial epithelium reveals multiple, discontinuous sites of $3 p$ allele loss and three regions of frequent breakpoints. Cancer Res 2000, 60:1949-1960

69. Mao L, Lee JS, Kurie JM, Fan YH, Lippman SM, Lee JJ, Ro JY, Broxson A, Yu R, Morice RC, Kemp BL, Khuri FR, Walsh GL, Hittelman WN, Hong WK: Clonal genetic alterations in the lungs of current and former smokers. J Nat/ Cancer Inst 1997, 89:857-862

70. Wistuba II, Behrens C, Milchgrub S, Bryant D, Hung J, Minna JD, Gazdar AF: Sequential molecular abnormalities are involved in the multistage development of squamous cell lung carcinoma. Oncogene 1999, 18:643-650

71. Belinsky SA, Nikula KJ, Palmisano WA, Michels R, Saccomanno G, Gabrielson E, Baylin SB, Herman JG: Aberrant methylation of p16(INK4a) is an early event in lung cancer and a potential biomarker for early diagnosis. Proc Natl Acad Sci USA 1998 , 95:11891-11896

72. Nuovo GJ, Plaia TW, Belinsky SA, Baylin SB, Herman JG: In situ detection of the hypermethylation-induced inactivation of the p16 gene as an early event in oncogenesis. Proc Natl Acad Sci USA 1999, 96:12754-12759

73. Zochbauer-Muller S, Fong KM, Virmani AK, Geradts J, Gazdar AF, Minna JD: Aberrant promoter methylation of multiple genes in non-small cell lung cancers. Cancer Res 2001, 61:249-255

74. Fisseler-Eckhoff A, Rothstein D, Muller KM: Neovascularization in hyperplastic, metaplastic and potentially preneoplastic lesions of the bronchial mucosa. Virchows Arch 1996, 429:95-100

75. Fontanini G, Calcinai A, Boldrini L, Lucchi M, Mussi A, Angelett CA, Cagno C, Tognetti MA, Basolo F: Modulation of neoangiogenesis in bronchial preneoplastic lesions. Oncol Rep 1999 6:813-817

76. Fisseler-Eckhoff A, Prebeg M, Voss B, Muller KM: Extracellular matrix in preneoplastic lesions and early cancer of the lung. Pathol Res Pract 1990, 186:95-101

77. Kayser K, Andre S, Bovin NV, Zeng FY, Gabius HJ: Preneoplasiaassociated expression of calcyclin and of binding sites for synthetic blood group $\mathrm{A} / \mathrm{H}$ trisaccharide - exposing neoglycoconjugates in human lung. Cancer Biochem Biophys 1997, 15:235243

78. Piyathilake CJ, Frost AR, Manne U, Bell WC, Weiss $\mathrm{H}$, Heimburger DC, Grizzle WE: The expression of fatty acid synthase (FASE) is an early event in the development and progression of squamous cell carcinoma of the lung. Hum Pathol 2000, 31:10681073

79. Tolnay E, Wiethege T, Muller KM: Expression and localization of thrombomodulin in preneoplastic bronchial lesions and in lung cancer. Virchows Arch 1997, 430:209-212

80. Piyathilake CJ, Frost AR, Weiss H, Manne U, Heimburger DC, Grizzle WE: The expression of Ep-CAM (17-1A) in squamous cell cancers of the lung. Hum Pathol 2000, 31:482-487

81. Mori M, Tezuka F, Chiba R, Funae Y, Watanabe M, Nukiwa T, Takahashi T: Atypical adenomatous hyperplasia and adenocarcinoma of the human lung: their heterology in form and analogy in immunohistochemical characteristics. Cancer 1996, 77:665674

82. Kitamura $H$, Kameda $Y$, Ito $T$, Hayashi $H$, Nakamura $N$, Nakatani $Y$, Inayama $Y$, Kanisawa M: Cytodifferentiation of atypical adenomatous hyperplasia and bronchioloalveolar lung carcinoma: immunohistochemical and ultrastructural studies. Virchows Arch 1997, 431:415-424 
83. Hosomi $Y$, Yokose $T$, Hirose $Y$, Nakajima R, Nagai K, Nishiwaki $Y$, Ochiai A: Increased cyclooxygenase 2 (COX-2) expression occurs frequently in precursor lesions of human adenocarcinoma of the lung. Lung Cancer 2000, 30:73-81

84. Wardlaw SA, March TH, Belinsky SA: Cyclooxygenase-2 expression is abundant in alveolar type II cells in lung cancer-sensitive mouse strains and in premalignant lesions. Carcinogenesis 2000, 21:1371-1377

85. Zhong H, De Marzo AM, Laughner E, Lim M, Hilton DA, Zagzag D, Buechler $P$, Isaacs WB, Semenza GL, Simons JW: Overexpression of hypoxia-inducible factor 1alpha in common human cancers and their metastases. Cancer Res 1999, 59:58305835

86. Claudio PP, Caputi M, Giordano A: The RB2/p130 gene: the latest weapon in the war against lung cancer? Clin Cancer Res 2000, 6:754-764

87. Nakanishi K, Hashizume S, Kato M, Honjoh T, Setoguchi Y, Yasumoto K: Elevated expression levels of the 14-3-3 family of proteins in lung cancer tissues. Hum Antibodies 1997, 8:189194

88. Tockman MS, Mulshine JL, Piantadosi S, Erozan YS, Gupta PK, Ruckdeschel JC, Taylor PR, Zhukov T, Zhou WH, Qiao YL, Yao SX: Prospective detection of preclinical lung cancer: results from two studies of heterogeneous nuclear ribonucleoprotein A2/B1 overexpression. Clin Cancer Res 1997, 3:2237-2246

89. Qiao YL, Tockman MS, Li L, Erozan YS, Yao SX, Barrett MJ, Zhou WH, Giffen CA, Luo XC, Taylor PR: A case-cohort study of an early biomarker of lung cancer in a screening cohort of Yunnan tin miners in China. Cancer Epidemiol Biomarkers Prev 1997, 6:893-900

90. De Flora S, Balansky R, Scatolini L, Di Marco C, Gasparini L, Orlando $M$, Izzotti $A$ : Adducts to nuclear DNA and mitochondrial DNA as biomarkers in chemoprevention. IARC Sci Publ 1996, 139:291-301

91. Saccomanno G, Archer VE, Auerbach O, Saunders RP, Brennan LM: Development of carcinoma of the lung as reflected in exfoliated cells. Cancer 1974, 33:256-270

92. Venmans BJ, van Boxem TJ, Smit EF, Postmus PE, Sutedja TG: Outcome of bronchial carcinoma in situ. Chest 2000, 117:1572-1576

93. Ponticiello A, Barra E, Giani U, Bocchino M, Sanduzzi A: P53 immunohistochemistry can identify bronchial dysplastic lesions proceeding to lung cancer: a prospective study. Eur Respir J 2000, 15:547-552

94. Suzuki K, Nagai K, Yoshida J, Yokose T, Kodama T, Takahashi K, Nishimura M, Kawasaki H, Yokozaki M, Nishiwaki Y: The prognosis of resected lung carcinoma associated with atypical adenomatous hyperplasia: a comparison of the prognosis of welldifferentiated adenocarcinoma associated with atypical adenomatous hyperplasia and intrapulmonary metastasis. Cancer 1997, 79:1521-1526

95. Takigawa N, Segawa Y, Nakata M, Saeki H, Mandai K, Kishino D, Shimono M, Ida M, Eguchi K: Clinical investigation of atypical adenomatous hyperplasia of the lung. Lung Cancer 1999, 25:115-121 